\title{
THE EFFECT OF TEACHER PROFESSIONALISM ON THE PERFORMANCE OF CHRISTIAN RELIGIOUS EDUCATION TEACHERS, ELEMENTARY SCHOOLS IN SURABAYA CITY
}

\author{
Sulistiani $^{1)}$, Surja Permana ${ }^{2}$ \\ ${ }^{1)}$ Evangelical Theological Seminary of Indonesia - Surabaya \\ E-mail: sulistiani@sttii-surabaya.ac.id \\ 2) Evangelical Theological Seminary of Indonesia - Surabaya \\ E-mail: surjapermana@sttii-surabaya.ac.id
}

\begin{abstract}
Education is important for development in all fields in Indonesia. Whether or not the quality of education will determine the human resources produced. In the world of education, teachers play an important role, meaning that the quality of this nation's education is indirectly determined by the quality of educators or teachers. Based on the Unesco agency, Indonesia is one of the countries that has a low quality of education. The quality or low level of teacher professionalism will have an impact on low-performance results. Low teacher performance will affect the quality of students and the quality of education produced. The teacher's performance includes lesson planning, learning implementation, and learning assessment. In this study, the professionalism of teachers can be influenced by several factors, including the level of academic qualifications, certification, and teacher competence. If these three things can be fulfilled by a teacher, it is expected that the teacher has high professionalism to carry out his duties professionally so that it has an impact on better performance.
\end{abstract}

Keywords: Teacher Qualifications, Certifications, Competencies and Performance.

\section{INTRODUCTION}

Education is important for development in all fields of Indonesia. Whether or not the quality of education will determine the human resources produced. In the world of education, the teacher plays an important role, Syaiful Bahri Djamarah in his book on teachers and students defines that the teacher is the human element in education. The teacher is a human figure who occupies a position and plays an important role in education.[1] In other words, the quality of this nation's education is indirectly determined by the quality of educators or teachers.

Indonesia is one of the countries that has a low quality of education, this is also expressed by Gaol based on the Unesco agency which states that the quality of teachers in Indonesia as an important component in education, is 
ranked 14th out of 14 developing countries in the world.[2] Problems about the low quality of these teachers will indirectly have an impact on their performance. The same statement was expressed by Yunus that the reality of the low human development index (HDI) and low quality education in Indonesia is one result of the low performance of teachers.[3] Many factors can cause the low quality of education, one of which is the teacher's performance factor.

From the above phenomenon, it can be seen that the quality or level of low teacher professionalism will have an impact on low-performance results. The low performance will affect the quality of students and the quality of education produced. Low teacher performance can be caused by many factors. For this reason, researchers need to conduct an assessment of teacher performance which will be discussed in the background below. Based on the description above, the researcher found several problems that arose regarding teacher performance.

First, based on data released by the Ministry of Education and Culture, the number of teachers in Indonesia as of December 2017 which was presented by the Ministry of Education and
Culture of the Republic of Indonesia on January 16, 2018, stated that the current number of teachers was 3,017,296 while teachers who do not meet the qualification requirements academic and professional certificates as many as $1,625,141$ teachers, or $(53.86 \%)[4]$ This shows that there are still many educators who do not meet the requirements as educational staff. This means that the current condition of teachers in Indonesia is still below the expected achievement target.

According to Taufik, in Indonesia, only 7 provinces achieved the UKG (teacher competency test) score, namely Bali, Bangka Belitung District, Jakarta, West Java, East Java, Central Java, and Yogyakarta.[5] Meanwhile, 27 other provinces are in Indonesia. Indonesia still not reach the minimum. This is what causes many of the educators who teach not in accordance with their fields because they do not meet the standards of teacher competency testing.

Second, According to the report submitted by the head of the institution Central Kalimantan Education Quality Assurance Krisnayadi Toendan, expressed concern because there are still many teachers who are technologically stumped when taking the online teacher competency test. There are still many teachers who cannot operate internet facilities, especially 
old teachers, old teachers who are domiciled in the regions.[6] The minister of education and culture, Muhadjir Efendy, in written remarks on the commemoration of the national teacher's day and the 73rd birthday of PGRI at the West Java province level, said that teachers must be able to take advantage of advances in information technology to improve the quality of the teaching and learning process and prepare resources. superior human resources.[7] There are still many teachers who have not mastered Information technology in the era of globalization will have an impact on the quality of teacher performance.

For this reason, educators are required to be able to adapt to technological developments so that the learning process does not experience obstacles. Third, a journal written by Hasbullah et al, shows that reporting of evaluation results and implementation of improvement and enrichment programs have never been held. So that teachers never know what percentage of the level of completeness of learning has been carried out in the teaching and learning process.[8]

The same opinion was also expressed by Siska Agusthia in her journal about the obstacles of teachers in implementing remedial stating "In practice in the field or in the classroom there are also several obstacles faced by teachers in implementing remedial, including adjusting the time the teacher has to retest students and compiling assignments, questions and others that must be done have not reached the minimum completeness criteria.[9] This can mean that if the teacher does not conduct an evaluation, the teacher cannot know the extent to which students understand each material presented in the learning process activities.

Fourth, most of the teachers still use traditional or conventional teaching methods, about that Hasbullah and his friends in their journal Learning Strategies wrote that, in general, the implementation of teaching and learning using conventional learning methods that will continue to lead to boredom, because students are less involved actively.

active in learning activities.[10] According to Winarno Surachman, this method approach is less able to attract students' interest, thus resulting in low students' reasoning abilities".[11] If this continues, it will have an impact on students' interest in learning to decrease and children's creative power to be less developed. Fifth, in her journal on improving elementary school teachers in preparing learning implementation plans, Kusumawati said, the competence of teachers in preparing learning 
implementation plans was not sufficient.

$$
\text { (only reached 59.375\%).[12] }
$$

Teachers do not make lesson plans themselves, many teachers think that ownership of learning implementation plans can be done by copying the documents prepared by another school. So that it has an impact on the number of learning implementation plans that are not in accordance with the needs of each school.[13]

Learning implementation plans are made with the aim that the learning process can be carried out properly, planned, and in accordance with the character and abilities of students. If this task is ignored by the teacher, surely the learning process will just run without a clear plan and purpose so that student learning outcomes are not optimal.

\section{RESEARCH METHOD}

The research method used in this study is a quantitative research method (Positive). Positive research relies on quantification in data collection and analysis to test the established hypothesis.[14] The positivist research approach is an investigation using the scientific method, namely a step-by-step procedure steps in solving problems on the basis of empirical observations [15] The main elements of positivist research are as follows: Starting by sensing a difficulty or complexity, translating that complexity into a statement, gathering information, making hypotheses, establishing target group, draw one or more required samples, collect data, analyze data, test hypotheses, and interpret the results.[16]

The research method used in this research is a quantitative research design with a survey method. It is called a survey because this study uses a direct population to be a representative sample to draw conclusions using a questionnaire or questionnaire as a data collector.[17]

This research was conducted with the aim of testing the hypothesis that states the effect of the independent variable (independent variable) on the dependent variable (dependent variable). As for the independent variable is the professionalism of the teacher (hereinafter named variable $\mathrm{X})$, then the dependent variable is the performance of Christian religious education teachers in Surabaya (hereinafter named variable $\mathrm{Y}$ ). The variables in this study are as follows:

$\mathrm{X}=$ Teacher professionalism

$\mathrm{X} 1$ = Academic qualifications and teacher certification

$\mathrm{X} 2=$ Teacher competence

$\mathrm{Y}=$ PAK Elementary School Teacher Performance in Surabaya

Y1 = Planning lessons 
Y2 = Carry out learning

Y3 = Evaluating learning

\section{RESULTS AND DISCUSSION}

\section{Understanding Teacher Professionalism}

Teacher professionalism is a set of functions and tasks in the field of education based on the expertise gained through education and special training in the field of work that is able to develop their work scientifically in addition to being able to pursue their professional field throughout their lives.[18]

The same thing too Sutarmanto expressed that teacher professionalism is the freedom for teachers to develop effective learning at a higher standard continuously with a full sense of responsibility.[19] Thorough explanations above it can be concluded that teacher professionalism is a commitment from all members to continuously improve their professional abilities and authority and develop strategies that will be used in carrying out learning activities.

Teacher professionalism also talks about the quality of teachers who have special abilities and expertise in the field of teaching, so they are able to carry out their duties and functions as teachers well and maximally.[20] The same is said also by Ibrahim Bawadal about teacher professionalism, namely the ability of teachers to manage themselves in carrying out their daily tasks.[21] The ability in question is the teacher's ability to perform tasks principally as an educator which includes the ability to plan, implement and evaluate learning. Teacher professionalism is also a way to improve the education profession which has been considered by some people to be low, professionalism provides the possibility of improvement and self-development of teachers in order to provide better services and maximize their competence.[22] Teacher professionalism is a strategy in improving teacher performance. To maximize their competence. According to Moch Usman, teacher professionalism is a strategy in improving teacher performance in implementing their duties.[23] So that through professionalism, teachers are expected to provide improvements in the quality of education that will affect student achievement. [24] From the explanation above, the researcher can conclude that teacher professionalism is one way for teachers or educators to improve and develop their profession continuously so that they can carry out their duties professionally and have an impact on student achievement. 


\section{Understanding Teacher Performance}

In relation to the world of education, teacher performance can be defined as the ability of teachers to demonstrate various skills and competencies they have. The essence of teacher performance is none other than the ability of teachers to show their skills or competencies in the real world of work.[25]

Teacher performance is all activities carried out in carrying out their mandate and responsibility in educating, teaching and guiding, directing, and guiding students in achieving the level of maturity and maturity.[26] Another opinion from Tabrani Rusyan states that teacher performance is carrying out the learning process both in the classroom and outside the classroom in addition to working on other activities, such as working on school administration and learning administration, implementing guidance and services to students, as well as carrying out assessments.[27]

Furthermore, Manullang stated that "teacher performance is the ability shown by the teacher in carrying out his duties and work, the performance is said to be good or satisfactory. if the goals achieved are in accordance with predetermined standards [28] Still in relation to the performance of teachers, Manullang added that the quality and quantity of work achieved by a teacher in carrying out their duties are in accordance with their responsibilities which include preparing a program of learning activities, implementing learning, implementing evaluations, and analyzing evaluations" [29] Further Supardi explained that "Teacher performance is not only shown by the work, but also by behavior at work. Teacher performance can be seen clearly in the learning shown from the acquisition of learning outcomes produced by the students. The quality of good teacher performance will show good student learning outcomes".[30]

Based on the various opinions described above, it can be concluded that teacher performance is an achievement or work that has been achieved by a teacher when carrying out and carrying out his responsibilities as executor of learning activities. Whether or not the performance of an educator or teacher can be seen from the results or quality of their students.

\section{Linearity Test}

The linearity test aims to determine whether there is a linear relationship or not. Variables significantly, research variables can be said to have . has a linear relationship if the significance is less than 0.05. 5 The linearity test is calculated by using a linear regression test or linearity test for deviation from linearity between the teacher professionalism variable (X) and the 
performance variable for Christian religious education teachers in elementary schools in Surabaya, which is less than 0.05 , so it can be concluded that between the variables of teacher professionalism and teacher performance variable there is a linear relationship. The overall picture is like the table below:

Table 4.5

\begin{tabular}{|c|c|c|c|c|c|c|c|}
\hline \multicolumn{8}{|c|}{ ANOVA Table } \\
\hline & & & \begin{tabular}{c|} 
Sum of \\
Squares
\end{tabular} & df & $\begin{array}{l}\text { Mean } \\
\text { Square }\end{array}$ & $\mathrm{F}$ & Sig. \\
\hline \multirow{5}{*}{$\begin{array}{l}\text { Kinerja } \\
\text { Guru } \\
\text { Profesiona } \\
\text { lisme Guru }\end{array}$} & $\begin{array}{l}\text { Between } \\
\text { Groups }\end{array}$ & (Combined & 644,486 & 14 & 46,035 & 6,099 &, 000 \\
\hline & & Linearity & 555,365 & 1 & 555,365 & 73,581 &, 000 \\
\hline & & $\begin{array}{l}\text { Deviation } \\
\text { from } \\
\text { Linearity }\end{array}$ & 89,122 & 13 & 6,856 & 908 & ,547 \\
\hline & Within Gro & & 709,477 & 94 & 7,548 & & \\
\hline & Total & & 1353,963 & 108 & & & \\
\hline
\end{tabular}

\section{Hypothesis test}

This subchapter will be discussed as well as answer the thesis hypothesis. The third hypothesis test was carried out by simple correlation analysis, determination of variance (r2yn),), linear regression line equation with line equation $=\mathrm{a}+\mathrm{Xn}$, and regression significance test $(F)$ through the Anova table. simple correlation significance test (t-test) The explanation is as follows: The research hypothesis on the effect of teacher professionalism on teacher performance at the Christian Religious Education Elementary School in Surabaya, the results are as shown in the table below:
Table 4.6.

Simple Correlation Calculation Results between $\mathrm{X}$ and $\mathrm{Y}$

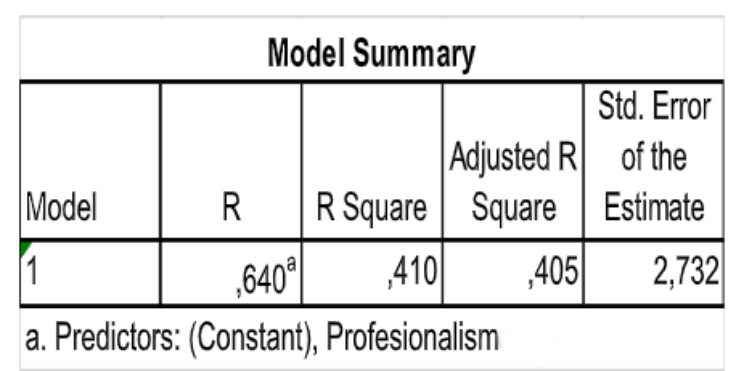

Based on the table above, the ryx value was found, which was 0.640 and was positive. This means if the professionalism of teachers increases, the performance of Christian religious education teachers in elementary schools in Surabaya will also increase.

The magnitude of the increase in the relationship between teacher professionalism and the performance of Christian religious education teachers in elementary schools in Surabaya is 0.640. Guidelines for providing an interpretation of correlation coefficients are as follows:

$$
\begin{aligned}
& 0.00-0.199=\text { very low } \\
& 0.20-0.399=\text { low } \\
& 0.40-0.599=\text { moderate } \\
& 0.60-0.799=\text { height } \\
& 0.80-0.1000=\text { very high } .
\end{aligned}
$$

Then the relationship between the variables $\mathrm{X}$ and $\mathrm{Y}$ is included in the category high relationship. The direction of the relationship between the two is positive, which shows that the higher the 
professionalism of the teacher is a teacher, the higher the performance of Christian religious education teachers in elementary schools throughout the city of Surabaya. And vice versa.

From the results of the analysis also obtained the value of ryx2 (coefficient of determination) of 0.410 or $41 \%$. This means that the contribution of the teacher professionalism variable in shaping the teacher performance variable is $41 \%$ while the remaining $59 \%$ is explained by other reasons outside the research model.

\section{Discussion of Research Results}

Based on the results of the hypothesis, it shows that there is a tendency to influence teacher professionalism on the performance of elementary school Christian religious education teachers is high. From the results of a simple regression statistical test between the variable of teacher professionalism $(\mathrm{X})$ on the performance of Christian religious education teachers Elementary schools throughout the city of Surabaya were found to have an ryx value of 0.640 and a positive value.

This means, the magnitude of the relationship between the influence of teacher professionalism on the performance of Christian religious education teachers in elementary schools in Surabaya is 64\%, then the relationship between variables $\mathrm{X}$ and $\mathrm{Y}$ is included in the category of high relationship.

The direction of the relationship between the two is positive, which shows that the higher the professionalism of teachers, the higher the performance of Christian religious education teachers Elementary Schools throughout the city of Surabaya increased, and vice versa.

The results of the analysis also obtained the value of ryx 2 (coefficient of determination) by 0.410 or $41 \%$. This means that the contribution of the teacher professionalism variable to the performance of Christian religious education teachers in elementary schools in Surabaya is $41 \%$ while the remaining $59 \%$ is explained by other reasons outside the research model. It was concluded that the teacher's professional influence was significant on \&lt; 0.05 .

When viewed from the population, the $\mathrm{t}$-value is 8.626 and it is significant at \&lt; 0.05 . It means that the variable of teacher professionalism has a significant effect on the performance variable of Christian religious education teachers in elementary schools in Surabaya. As for the linear regression line equation, $=10.066+$ $0.713 \mathrm{X}$ This means that each improvement in understanding of teacher professionalism increases by one time, then the performance of teachers of Christian religious education 
in elementary schools in Surabaya will increase by 0.713 times. The results of data analysis in this study prove that the initial hypothesis which states that there is a relationship between the influence of teacher professionalism on the performance of Christian religious education teachers in elementary schools in Surabaya is proven.

\section{CONCLUSION}

Based on the results of data processing and discussions that have been carried out, the researchers will conclude the results of research on the influence of teacher professionalism on the performance of Christian religious education teachers in elementary schools throughout the city Surabaya.

The conclusions of this study are as follows: First, there is a relationship between the teacher professionalism variable $(\mathrm{X})$ and the teacher performance variable (Y) with an ryx value of 0.640 and a positive value. This means that the relationship between the teacher professionalism variable $(\mathrm{X})$ and the teacher performance variable (Y) is directly proportional, meaning that the increase in the variable $\mathrm{X}$ coincides with the increase in the variable $(\mathrm{Y})$.

Second, the contribution of the teacher professionalism variable (X) informing the variable The performance of
Christian religious education teachers in elementary schools in Surabaya (Y) with a ryx value of 2 (coefficient of determination) of 0.410 or $41 \%$. This means that the variable $\mathrm{X}$ Professionalism teachers influence variable $\mathrm{Y}$ Teacher performance is $41 \%$ and the remaining $59 \%$ is influenced by other factors outside the research model. The t-factors can be the teacher's intellectual level, experience, salary, facilities, and environmental factors.

Referring to the discussion, it can be concluded that teacher professionalism (X) has a positive effect on the performance of Christian religious education teachers (Y) with a total effect of $41 \%$. This positive effect means that the higher the level of the professionalism of a Christian religious education teacher will affect the improvement of the teacher's performance.

Third, there is a significant relationship between teacher professionalism (X) and the performance variable of Christian religious education teachers in elementary schools throughout the city of Surabaya (Y) with an F value of 6.099 which is significant at $<0.05$. Fourth, there is a significant influence between teacher professionalism $(\mathrm{X})$ on the variable performance of Christian religious education teachers in elementary schools in Surabaya (Y) with a t value of 8.626 and it is significant at $<0.05$. Fifth, the linear 
regression line equation results in $=10.066$ $+0.713 \mathrm{X}$. It means that every improvement in the professionalism of Christian religious education teachers increases once, their performance will increase by 0.713 times. So based on the results of the research above, it can be concluded that the hypothesis

This study shows that there is an influence between the variables of teacher professionalism $(\mathrm{X})$ on the performance of teachers (Y) in Christian religious education in elementary schools throughout the city of Surabaya.

\section{REFERENCES}

[1]. Syaiful Bahri Djamarah, Teachers and Students in Educational Interaction, (Jakarta: PT. Rineka Cipta),1.

[2]. Gaol, N.T.L. Improving the quality of Indonesian education. Retrieved from 7 June 2019. http://harian.analisadaily. com/opin/news/Improving the quality of education-Indonesia 2019.

[3]. Yunus, S. (2018). Teachers or Curriculum; The Urgent Point of Indonesian Education Quality? Accessed from coil.com/syarif-yunus/guru or curriculum-dot-urgen-quality of Indonesian education, 2019

[4]. (Kemendikbud, (2018, December 10:27) Conditions and Alternative Solutions for Honorary Teachers. Exposure of the
Minister of Education and Culture at the Commission X Working Meeting, Jakarta).

[5]. Taufik, M ( 2018, September 14 ) Budget to Improve teacher quality. Compass, 1-15.)

[6].jurnalasia.com/opini/guru-harusmaster-tekhnologi, accessed January 1, 2016 )

[7]. Tempo.co, 10 December 2018 teachers must master technology

[8]. Hasbullah et al, Teaching and Learning Strategies in Efforts to Improve Learning Outcomes of Islamic Religious Education, (Banten: Journal of Islamic Religious Education, 2019), 18

[9]. Siska Agusthia, Teacher Obstacles in Remedial Implementation of Student KKM, (Aceh: Unsyiah Journal, 2018), 20

[10]. Hasbullah et al, Teaching and Learning Strategies in Efforts to Improve Learning Outcomes of Islamic Religious Education, (Banten: Journal of Islamic Religious Education, 2019), 18

[11]. Winarno Surachman, National Teaching Methodology, (Bandung: Tarsito, 1998), 35

[12]. Kusumawati, increasing the competence of elementary school teachers in preparing lesson plans and implementing learning using peer tutors (Salatiga: ejournal.uksw.edu/satyawidya /article Vol 32 No 2 (2016), 2

[13]. Yadi Jaya Dipura, in house training to 
improve the ability of teachers in preparing lesson plans (Karawang: idaarah journal, vol. II, NO. 2, December 2018), 260.

[14]. Sarmanu, Basic Quantitative, Qualitative and Statistical Research Methods (Surabaya: Air Langga Universitas Pres, 2017), 9.

[15]. Conny R. Setiawan, Qualitative Research Methods, Types, Characteristics and Advantages (Jakarta: Grasindo, t.t), 5.

[16]. Sugiyono, Quantitative, Qualitative and $R \& D$ Research Methods, (Bandung: Alfabeta, 2011),

[17]. Fred N. \& Howard B. Lee, Foundations of Behavioral Research (Forth Worth: Harcout College Publisher, 2000), 559.

[18]. Nurjayanti, The Nature of Teacher Professionalism (Kendari: Journal of Chapter II Theoretical Foundations 2016) ,19

[19]. Sutarmanto, Competence and Professionalism of Early Childhood Education Teachers (Journal of Vision Science Education 2.

[20].Nur Nafisatul

Fithiyah,Professionalism

Teacher (Surabaya: Journal of Multi-Site

Studies at Al Bukhori Elementary School, 2020), 15

[21]. Ibrahim Bafadal, Increasing Teacher Professionalism (Jakarta: PT. Bumi Aksara, 2000)
[22]. Kunandar, professional teacher ( Jakarta : PT Raja Grafindo Persada 2001), 48

[23]. Moh. Usman uzer, Becoming a Professional Teacher Second Edition ( Bandung: Remadja Rosadakarya 2002) , 133

[24]. Munawwaroh, The Effect of Teacher Professionalism on Student Learning Outcomes (Makassar: Journal 2012), 26-62 [25]. Ministry of National Education 2004 , [26]. Muhktar, Islamic Religious Education Learning Design, (Jakarta: Misakaka Galiza,, 2003), 84

[27]. Tabrani Rusyan et al. Efforts to Improve Teacher Performance Culture, (Cianjur: CV. Dinamika Karya Cipta 2000), [28]. Manullang, Resi Adelina. The Influence of Teacher Performance on Middle School Student Learning Outcomes Negeri 4 Tanjung Jambung Timur 2017. Jambi: Scientific Journal of Batanghari University Jambi (Volume 17 2017) , 1 [29]. Manullang, Resi Adelina. The Effect of Teacher Performance on Student Learning Outcomes of SMP Negeri 4 Tanjung Jambung Timur 2017. Jambi: Scientific Journal of Batanghari University Jambi (Volume 17 2017) , 1

[30]. Supardi, Teacher Performance, ( Jakarta Rajda Grafindo Persada, 2013 ) , 55 